\title{
Hydrogen Autotrophy as a Transferable Genetic Character of Nocardia opaca $1 \mathrm{~b}$
}

\author{
By M. REH AND H. G. SCHLEGEL* \\ Institut für Mikrobiologie, Georg-August Universität Göttingen, Grisebachstrasse 8, D-3400 \\ Göttingen, Federal Republic of Germany
}

(Received 17 February 1981; revised 10 April 1981)

\begin{abstract}
A mating system to transfer the ability of growing autotrophically as a hydrogen bacterium (aut ${ }^{+}$marker) has been developed in Nocardia opaca strain 1b. Following filter mating between an $a u t^{+} t r p s t r$ strain and an aut strain, transconjugants of the phenotype Aut $^{+} \operatorname{Trp}^{+} \mathrm{Str}^{\mathrm{s}}$ were obtained. The number of recombinant colonies exceeded the number of revertants by a factor of $10^{5}$. This and other crosses indicated that only the $a u t^{+}$marker is transferred. Among other markers tested (growth on lactate and benzoate) no new combinations were found. A few strains of the Rhodococcus taxon were tested for their ability to act as recipients. Transconjugants of Rhodococcus erythropolis and Corynebacterium hydrocarboclastus able to grow autotrophically were isolated. Most transconjugants were able to act as $a u t^{+}$donors, but with different recipient spectra. As indicated by the observation of sectored colonies after autotrophic growth, by the measurement of the frequency of loss of autotrophy compared to auxotrophic markers, and by the effect of mitomycin $\mathrm{C}$ treatment, the $a u t^{+}$marker does not become integrated in the recipient chromosome in a stable state. It is probably located on a plasmid.
\end{abstract}

\section{IN TRODUCTION}

The ability to grow as a hydrogen-oxidizing bacterium, i.e. with gaseous hydrogen as the only electron donor and carbon dioxide as carbon source, occurs among various bacteria belonging to different taxonomic groups. The list of hydrogen-oxidizing bacteria comprises 23 species of 9 genera (Bowien \& Schlegel, 1981). Hydrogen-oxidizing bacteria are not obligately bound to chemolithoautotrophic growth and usually grow at higher rates under chemoorganotrophic conditions. Growth as a hydrogen bacterium requires three enzyme functions not normally present in a chemoorganotrophic bacterium: hydrogenase makes hydrogen accessible as a source of energy and reducing power for biosynthesis, and phosphoribulokinase and ribulosebisphosphate carboxylase supplement the enzymes of gluconeogenesis and of the pentose phosphate pathway.

Nocardia opaca strain $1 \mathrm{~b}$ represents a special type among the hydrogen-oxidizing bacteria for the following reasons. (1) Its doubling time during autotrophic growth is $7.5 \mathrm{~h}$ (Aggag \& Schlegel, 1973), significantly longer than that of other hydrogen-oxidizing bacteria, e.g. the doubling time of Alcaligenes eutrophus is $2.5 \mathrm{~h}$. (2) In contrast to the majority of hydrogen bacteria, which contain only a membrane-bound hydrogenase, and to a minority of species, which contain both a membrane-bound and a soluble $\mathrm{NAD}^{+}$-reducing hydrogenase (e.g. Alcaligenes eutrophus), $N$. opaca contains only a soluble, $\mathrm{NAD}^{+}$-reducing hydrogenase (Aggag \& Schlegel, 1974; Schneider \& Schlegel, 1977). Furthermore, in N. opaca isoenzymes of fructose-bisphosphatase are present, and form A is detectable only in autotrophically grown cells (Amachi \& Bowien, 1979). The isoenzymes may be involved in both physiological functions, gluconeogenesis and the Calvin cycle. This type of functional separation has not 
been found in $A$. eutrophus (Abdelal \& Schlegel, 1974) which is the most intensively studied hydrogen bacterium so far.

Taxonomical considerations prompted us to include $N$. opaca in the conjugational system discovered in Rhodococcus erythropolis (Adams \& Bradley, 1963; Brownell, 1978) and to make the autotrophic character accessible to genetic analysis (Reh \& Schlegel, 1975). A further special feature of the autotrophic properties of this bacterium became evident. Autotrophy was the only character which was transferred by conjugation, and it was never integrated into the recipient's genome in a stable state. The present study was aimed at examining the transfer and loss of the autotrophic character and at detecting a conjugative plasmid.

\section{METHODS}

Bacterial strains and bacteriophages. The bacterial strains used are listed in Table 1. Nocardia opaca strain $1 \mathrm{~b}$ (Aggag \& Schlegel, 1973) was kept in the culture collection of the Institut für Mikrobiologie, Göttingen. Nocardia opaca (ATCC 17039, DSM 364) and Corynebacterium hydrocarboclastus (ATCC 15592, DSM 311) were provided by the Deutsche Sammlung von Mikroorganismen (DSM), Göttingen. Rhodococcus erythropolis cE2 and $\mathrm{Ce} 3$, and the bacteriophages $\phi \mathrm{EC}, \phi \mathrm{C}$ and MNP7 were received from Dr G. H. Brownell (Medical College of Georgia, Augusta, Ga. U.S.A.). The bacteriophage $\phi \mathrm{B} 1$ appeared as a contaminant in a culture of Nocardia opaca lb growing autotrophically in a fermenter.

Media, growth conditions, and maintenance of strains. The mineral medium (MM) was that of Schlegel et al. (1961). It was solidified by the addition of $15 \mathrm{~g}$ agar $1^{-1}$. For autotrophic growth, cultures were incubated under an atmosphere of $\mathrm{H}_{2} / \mathrm{O}_{2} / \mathrm{CO}_{2}(80: 10: 10$; by vol.). For heterotrophic growth, $0.5 \%(\mathrm{w} / \mathrm{v})$ fructose (FM) or $0.5 \%$ $(\mathrm{w} / \mathrm{v})$ fructose plus $0.1 \%(\mathrm{w} / \mathrm{v})$ tryptose and $0.1 \%(\mathrm{w} / \mathrm{v})$ yeast extract $(\mathrm{FTY})$ or $0.5 \%(\mathrm{w} / \mathrm{v})$ of other carbon sources were added, and incubation was under air.

Antibiotics were used at the following concentrations: streptomycin sulphate, $300 \mu \mathrm{g} \mathrm{ml} \mathrm{l}^{-1}$; rifampicin, $20 \mu \mathrm{g}$ $\mathrm{ml}^{-1}$. The temperature for growth was $30^{\circ} \mathrm{C}$. The cell suspensions were diluted in saline containing $9 \mathrm{~g} \mathrm{NaCl}$, $0.2 \mathrm{~g} \mathrm{MgSO}_{4} .7 \mathrm{H}_{2} \mathrm{O}$ and $1 \mathrm{~g}$ Triton X-100 $\mathrm{l}^{-1}$. For maintenance, the heterotrophic strains were kept on agar slants ( $1.6 \%$ nutrient broth), and the autotrophic strains were grown on mineral agar slants under the gas mixture mentioned. The cultures were kept for many months at $4{ }^{\circ} \mathrm{C}$ without loss of viability.

Plaque test. Droplets of diluted lysates were placed on soft agar plates of peptone/yeast extract medium (Brownell et al., 1967) containing the dispersed bacteria. Formation of single plaques indicated the phage sensitivity of the bacteria.

Isolation of mutants. Mutation was induced by u.v. irradiation or by treatment with $N$-methyl- $N^{\prime}$ nitro- $N$-nitrosoguanidine (NMG). For u.v. treatment, heterotrophically growing cells were harvested in the stationary phase, washed and resuspended in saline (Triton-free). A $10 \mathrm{ml}$ portion of bacterial suspension $(2-5 \times$ $10^{7}$ cells $\left.\mathrm{ml}^{-1}\right)$ in an open Petri dish was exposed to a dose of u.v. irradiation ( $254 \mathrm{~nm}$ ) which inactivated $99.9 \%$ of the cells. For NMG mutagenesis, growing cell suspensions were transferred to 4 vol. fresh FTY medium, and 800 $\mu \mathrm{g} \mathrm{NMG} \mathrm{ml} \mathrm{m}^{-1}$ was added. After shaking at $30^{\circ} \mathrm{C}$ for $30 \mathrm{~min}$ the suspension was diluted with saline and plated out. Spontaneous mutants resistant to streptomycin or rifampicin were selected from FTY agar containing $300 \mu \mathrm{g}$ streptomycin $\mathrm{ml}^{-1}$ or $20 \mu \mathrm{g}$ rifampicin $\mathrm{ml}^{-1}$.

With the aim of isolating Aut $^{-}$variants the following curing agents were applied: mitomycin $\mathrm{C}$, acridine orange, nalidixic acid, novobiocin and hydroxyurea. Flasks containing FTY medium and various concentrations of these agents were inoculated with autotrophically grown bacteria $\left(10^{4}-10^{5}\right.$ cells $\left.\mathrm{ml}^{-1}\right)$. The suspensions without curing agents were diluted after $3 \mathrm{~d}$, and the cultures with the highest concentrations of curing agents just allowing growth were diluted after $6 \mathrm{~d}$; the diluted suspensions were spread on FTY agar. In addition, two mutagenic agents - ethyl methanesulphonate (EMS) and 8-methoxypsoralen - were applied. The former was applied at a concentration of $40 \mu \mathrm{g} \mathrm{ml}^{-1}$ for $3 \mathrm{~h}$. The latter was added to suspensions of the washed cells at a concentration of $50 \mu \mathrm{g} \mathrm{ml}^{-1}$ for 20 min. Then the suspension was diluted tenfold and exposed to u.v. irradiation resulting in an inactivation of $99.9 \%$ of the cells. The colonies that appeared were transferred by replica plating on to mineral agar plates, which were subsequently incubated under $\mathrm{H}_{2} / \mathrm{O}_{2} / \mathrm{CO}_{2}$, and on to $\mathrm{FM}$ agar plates. In some cases the Aut ${ }^{-}$derivatives occurred in sectored colonies. These were not studied further.

Crosses. Two mating methods were used. (1) 'Agar mating'. Colonies ( $3 \mathrm{~d}$ old) of the various mating partners were taken from FTY agar and streaked at right angles to each other. Usually the autotrophic partner was streaked first, and the potential recipients were applied subsequently. After incubation for $3 \mathrm{~d}$, the colony pattern was transferred by replica plating to selective media. The donor strain was eliminated by selection on $\mathrm{MM}$ /streptomycin agar or by selection against an auxotrophic marker. Colonies appearing in the area of the crossing streaks after 1 or 2 weeks indicated successful matings. 
Table 1. Bacterial strains

\begin{tabular}{|c|c|c|c|c|}
\hline Species & Strain & Relevant genotype* & Parent strain(s) & $\begin{array}{l}\text { Method of } \\
\text { production } \dagger\end{array}$ \\
\hline Nocardia opaca $1 \mathrm{~b}$ & $\begin{array}{l}\text { MR11 } \\
\text { MR 147 } \\
\text { MR 1450 } \\
\text { MR 1463 } \\
\text { MR 1857 } \\
\text { MR 1859 } \\
\text { MR113 } \\
\text { MR 1439 } \\
\text { MR 1852 } \\
\text { MR 1861 } \\
\text { MR 1469 } \\
\text { MR 1863 } \\
\text { MR1864 }\end{array}$ & $\begin{array}{l}\text { aut } \\
\text { aut } \\
\text { aut str } \\
\text { aut ben lac rif str } \\
\text { aut }{ }^{+} \text {ben lac rif str } \\
\text { aut }{ }^{+} \text {ben lac rif str } \\
\text { aut }{ }^{+} \text {phe } \\
\text { aut lac str } \\
\text { aut lac str } \\
\text { aut }{ }^{+} \text {str } \\
\text { aut trp str } \\
\text { aut } t^{+} \text {trp str } \\
\text { aut }\end{array}$ & 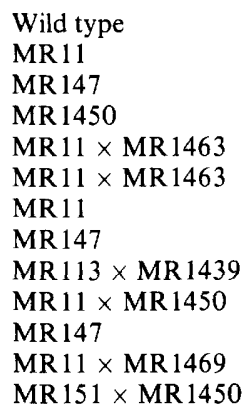 & $\begin{array}{l}\text { S } \\
\text { SA } \\
\text { UV, SA, UV } \\
\text { C } \\
\text { C } \\
\text { NMG } \\
\text { NMG, SA } \\
\text { C } \\
\text { C } \\
\text { UV, SA } \\
\text { C } \\
\text { C }\end{array}$ \\
\hline Rhodococcus erythropolis $\mathrm{Ce} 3$ & $\begin{array}{l}\text { MR12 } \\
\text { MR1235 } \\
\text { MR1621 } \\
\text { MR1625 }\end{array}$ & $\begin{array}{l}\text { str } \\
\text { aut }^{+} \\
\text {aut }^{+} s t r\end{array}$ & $\begin{array}{l}\text { Wild type } \\
\text { MR12 } \\
\text { MR113 × MR12 } \\
\text { MR151 × MR1235 }\end{array}$ & $\begin{array}{l}\text { SA } \\
\text { C } \\
\text { C }\end{array}$ \\
\hline Rhodococcus erythropolis $\mathrm{cE} 2$ & $\begin{array}{l}\text { MR 13 } \\
\text { MR132 } \\
\text { MR1623 }\end{array}$ & $\begin{array}{l}\text { str } \\
a u t^{+}\end{array}$ & $\begin{array}{l}\text { Wild type } \\
\text { MR } 13 \\
\text { MR } 11 \times \text { MR } 132\end{array}$ & $\begin{array}{l}\text { SA } \\
\text { C }\end{array}$ \\
\hline Nocardia opaca ATCC 17039 & $\begin{array}{l}\text { MR 15 } \\
\text { MR152 } \\
\text { MR151 }\end{array}$ & $\begin{array}{l}\text { str } \\
a u t^{+}\end{array}$ & $\begin{array}{l}\text { Wild type } \\
\text { MR } 15 \\
\text { MR } 1863 \times \text { MR } 15\end{array}$ & $\begin{array}{l}\text { SA } \\
\text { C }\end{array}$ \\
\hline $\begin{array}{l}\text { Corynebacterium hydrocarboclastus } \\
\text { ATCC } 15592\end{array}$ & $\begin{array}{l}\text { MR } 17 \\
\text { MR } 171 \\
\text { MR206 }\end{array}$ & $\begin{array}{l}\text { str } \\
a u t^{+} s t r\end{array}$ & $\begin{array}{l}\text { Wild type } \\
\text { MR } 17 \\
\text { MR } 11 \times \text { MR } 171\end{array}$ & $\begin{array}{l}\text { SA } \\
\text { C }\end{array}$ \\
\hline
\end{tabular}

* Genotype symbols: aut, autotrophy; str, streptomycin resistance; rif, rifampicin resistance; ben, benzoic acid; lac, lactose; phe, phenylalanine; trp, tryptophan.

$\dagger \mathrm{S}$, spontaneous occurrence after growth on complete medium; SA, spontaneous, selection on agar plates containing antibiotics; UV, u.v. irradiation; NMG, $N$-methyl- $N^{\prime}$-nitro- $N$-nitrosoguanidine mutagenesis; C, after conjugation.

(2) 'Filter mating'. For quantitative experiments the mating procedure of Matney \& Achenbach (1962) was used. Donor and recipient cells were grown in FTY medium until the stationary phase was reached, and then $0 \cdot 1$ $\mathrm{ml}$ of the recipient culture and $0.2 \mathrm{ml}$ of the donor suspension diluted to $10^{-2}$ were mixed in $2.5 \mathrm{ml}$ FTY medium and sucked on to a membrane filter (pore diameter $0.45 \mu \mathrm{m} ; 200 \mathrm{~mm}^{2}$ effective filter area). The filters carrying the uniformly mixed cells were incubated on FTY agar for the time periods indicated. Subsequently, the bacterial lawn was collected by rinsing with saline, homogenized, and diluted, and samples were plated on to selective media.

\section{RES U LTS \\ Loss of autotrophy}

Variants of Nocardia opaca strain lb unable to grow chemolithoautotrophically could be isolated from heterotrophic cultures without applying mutagenic agents (Table 2). These variants occurred more abundantly than each of the auxotrophic mutants. Treatment with u.v. or mitomycin C increased the frequency of $\mathrm{Aut}^{-}$variants sixfold and ninefold, respectively. Surprisingly, mutagenic agents such as methoxypsoralen, NMG and EMS, as well as nalidixic acid, novobiocin and hydroxyurea, resulted in an even greater increase in the frequency of $\mathrm{Aut}^{-}$variants. Growth in the presence of sublethal concentrations of acridine orange $\left(0.5 \mu \mathrm{g} \mathrm{ml}^{-1}\right)$, acriflavin $\left(0.5 \mu \mathrm{g} \mathrm{ml}^{-1}\right)$, ethidium bromide $\left(0.5 \mu \mathrm{g} \mathrm{ml}^{-1}\right)$, and rifampicin $\left(1 \mu \mathrm{g} \mathrm{ml}^{-1}\right)$ did not result in an increased frequency of $\mathrm{Aut}^{-}$variants. Aut $^{-}$ variants, whether occurring spontaneously, or isolated after mutagenic treatment, were completely stable; after plating $10^{9}$ cells on mineral agar and incubating under $\mathrm{H}_{2} / \mathrm{O}_{2} / \mathrm{CO}_{2}$, 
Table 2. Frequency of $A$ t $^{-}$variants and auxotrophic mutants

\begin{tabular}{|c|c|c|c|}
\hline Treatment & $\begin{array}{l}\text { Number of } \\
\text { colonies scored }\end{array}$ & $\begin{array}{l}\text { Frequency of } \\
\text { Aut }^{-} \text {variants* }\end{array}$ & $\begin{array}{c}\text { Frequency of } \\
\text { auxotrophic } \\
\text { mutants } \\
(\%)\end{array}$ \\
\hline None & 1497 & $0 \cdot 3$ & $<0.07$ \\
\hline Acridine orange $\left(0.5 \mu \mathrm{g} \mathrm{ml}^{-1}\right)$ & 2875 & 0.4 & 0.07 \\
\hline U.v. light $(254 \mathrm{~nm})$ & 956 & 1.8 & $1 \cdot 2$ \\
\hline Mitomycin $\mathrm{C}\left(0 \cdot 1 \mu \mathrm{g} \mathrm{ml}^{-1}\right)$ & 519 & $2 \cdot 7$ & 0.8 \\
\hline \multicolumn{4}{|l|}{ Methoxypsoralen $\left(100 \mu \mathrm{g} \mathrm{ml}^{-1}\right)$} \\
\hline plus u.v. light $(366 \mathrm{~nm})$ & 720 & $8 \cdot 3$ & $1 \cdot 0$ \\
\hline NMG $\left(450 \mu \mathrm{g} \mathrm{ml}^{-1}\right)$ & 1440 & $3 \cdot 0$ & $2 \cdot 0$ \\
\hline EMS $\left(40 \mu \mathrm{g} \mathrm{ml}^{-1}\right)$ & 1816 & $7 \cdot 5$ & $0 \cdot 2$ \\
\hline Nalidixic acid $\left(60 \mu \mathrm{g} \mathrm{ml}^{-1}\right)$ & 2792 & $8 \cdot 1$ & 0.07 \\
\hline Novobiocin $\left(3 \mu \mathrm{g} \mathrm{ml}^{-1}\right)$ & 2010 & $7 \cdot 7$ & $<0.05$ \\
\hline Hydroxyurea $\left(150 \mu \mathrm{g} \mathrm{ml}^{-1}\right)$ & 368 & $16 \cdot 3$ & 0.8 \\
\hline
\end{tabular}

* Aut ${ }^{-}$variants were selected by their ability to grow on FM agar but inability to grow chemolithoautotrophically on MM agar.

† Auxotrophic mutants were selected by their ability to grow on FTY agar plates but inability to grow on FM agar.

$\ddagger$ Spontaneous occurrence after growth on FTY medium (15 generations).

\title{
Table 3. Mating of Nocardia opaca strains MR1863 (aut ${ }^{+}$trp str) $\times$MR147 (aut)
}

\begin{abstract}
About $10^{8}$ cells of each strain were sucked on to a membrane filter either without or after mixing; the filters were incubated on FTY agar for $48 \mathrm{~h}$. The bacterial lawn was collected by rinsing with saline, homogenized and diluted, and samples were plated on selective media.
\end{abstract}

\begin{tabular}{lccccc}
\multirow{2}{*}{ Filter } & \multicolumn{5}{c}{ Viable counts on selective agar plates } \\
\cline { 2 - 3 } & $\mathrm{MM}+\mathrm{Str}$ & $\mathrm{FM}+\mathrm{Str}$ & $\mathrm{MM}+\mathrm{Trp}+\mathrm{Str}$ & $\mathrm{FM}$ \\
$\mathrm{H}$ & $\mathrm{H}_{2} / \mathrm{O}_{2} / \mathrm{CO}_{2}$ & $\mathrm{H}_{2} / \mathrm{O}_{2} / \mathrm{CO}_{2}$ & $\mathrm{Air}$ & $\mathrm{H}_{2} / \mathrm{O}_{2} / \mathrm{CO}_{2}$ & Air \\
$3 \times$ MR147 & $1.5 \times 10^{7}$ & $7.2 \times 10^{1}$ & $2.4 \times 10^{2}$ & $6.0 \times 10^{8}$ & $4.2 \times 10^{9}$ \\
& $1.4 \times 10^{2}$ & $1.4 \times 10^{3}$ & $4.8 \times 10^{2}$ & $3.7 \times 10^{9}$ & $2.6 \times 10^{3}$ \\
& 10 & 10 & 10 & 10 & $6.4 \times 10^{9}$
\end{tabular}

$\mathrm{Aut}^{+}$revertants were never detected. Loss of autotrophy is, therefore, a frequent and apparently irreversible event.

\section{Transfer of autotrophy between strains of Nocardia opaca}

As shown previously, the $a u t^{+}$marker can be transferred from Aut ${ }^{+}$strains of $N$. opaca $1 \mathrm{~b}$ to Aut $^{-}$strains (Reh \& Schlegel, 1975). Since matings in liquid cultures led to non-reproducible results, the mating partners were mixed on membrane filters which were laid on FTY agar.

The results of a three-factor cross between an aut trp str (MR 1863) and a aut (MR 147) partner are presented in Table 3. The selective marker was autotrophic growth. The only combination found was that of $a u t^{+}$with $\operatorname{trp}^{+}$and $s t r^{+}$(Table 3, column 1). The number of recombinant colonies exceeded the number of revertants by a factor of $10^{5}$. The recombinants were stable with respect to the trp and str markers, but they segregated Aut ${ }^{-}$variants; this is discussed below. The two other possible marker combinations, which should have resulted from chromosomal transfer, were not detectable.

The transfer frequency was not affected by incubating the membrane filters on agar plates containing DNAase I, RNAase or proteinase K. No transfer occurred in agar matings if the autotrophic partner had been killed by chloroform vapour prior to the addition of the heterotrophic partner. Furthermore, electron microscopic inspection of concentrated 


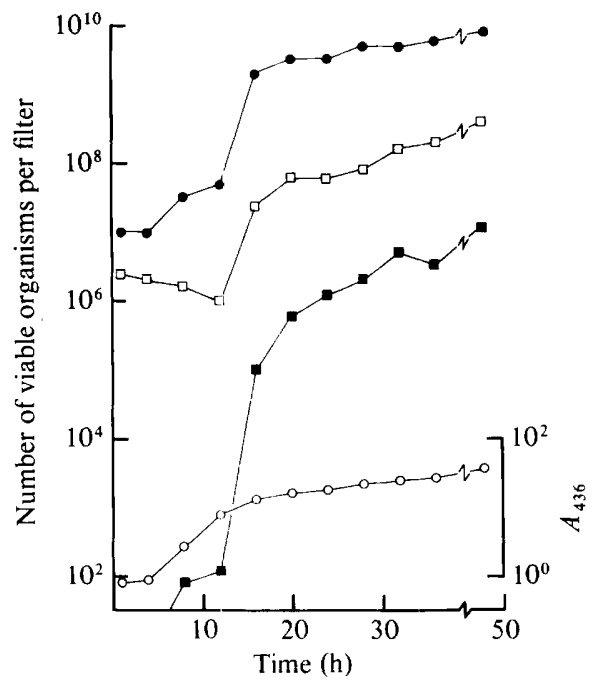

Fig. 1. Kinetics of aut transfer. About $2.6 \times 10^{6}$ cells of Nocardia opaca $1 \mathrm{~b}$ MR $11\left(\right.$ aut $^{+}$) and $10^{8}$ cells of MR 1463 (aut lac ben rif str) were mixed and sucked on to membrane filters, and the filters were incubated on FTY agar plates at $30^{\circ} \mathrm{C}$. At the times indicated the bacterial lawn was rinsed from one of the filters, evenly dispersed in suspension and plated out for counting. O, Turbidity $\left(A_{436}\right) ; \mathbf{O}$, viable count of MR 1463 on FTY plates containing streptomycin; $\square$, viable count of MR11 on lactose agar; $\mathbf{\square}$, transconjugants growing on MM agar containing streptomycin.

supernatants of cell suspensions did not reveal the presence of phage particles (unpublished observation). In liquid media the transfer appeared to be casual; evidently intimate cell contact on solid surfaces was required for the transfer. From these controls and observations the conclusion was drawn that in Nocardia opaca genetic transfer is due to conjugation.

The kinetics of the transfer of the $a u t^{+}$marker was followed in matings of wild-type $N$. opaca $1 \mathrm{~b}$ with the mutant MR1463 (aut ben lac rif str) (Fig. 1). The increase of cell density during growth on membrane filters, measured as the turbidity $\left(A_{436}\right)$ of the evenly resuspended cells, revealed two phases of exponential growth, a phase of rapid growth and starting at about the 15th hour - a phase of slow growth. During the first phase, the cell morphology was characterized by hyphae and long rods, during the second phase by irregular short rods. The morphological transition was reflected by the biphasic curve of the viable cell count. It was during this transitional period that the number of $a u t^{+} s t r$ transconjugants increased by five orders of magnitude.

Non-selected markers were examined in 50 transconjugants. All of them were $\mathrm{Lac}^{-} \mathrm{Ben}^{-}$Rif ${ }^{r}$. Attempts to isolate transconjugants of the type $\mathrm{Lac}^{+} \mathrm{Str}^{\mathrm{r}}$ and $\mathrm{Ben}^{+} \mathrm{Str}^{\mathrm{r}}$ failed. Plating on lactose/streptomycin and benzoate/streptomycin agar resulted in colony counts which were not higher than the number of revertants. These observations indicate that transfer of complete genomes did not occur; the genetic transfer appeared to be restricted to a part of the genome which harbours the genetic information for autotrophic growth. The function of the wild type was that of the donor strain, and the mutant MR1463 was the recipient.

The yield of transconjugants proved to be dependent on the ratio of donor cells and recipient cells in a linear fashion within two orders of magnitude (Fig. 2). When, however, the mixing ratio of donor and recipient cells exceeded $1: 100$, no further increase of the number of transconjugants occurred, for unknown reasons. The growth rates of the donor and recipient cells in the bacterial lawn were almost the same. If, at the favourable donor : recipient ratio, the cell density on the membrane filters was varied, the yield of transconjugants varied only slightly. 


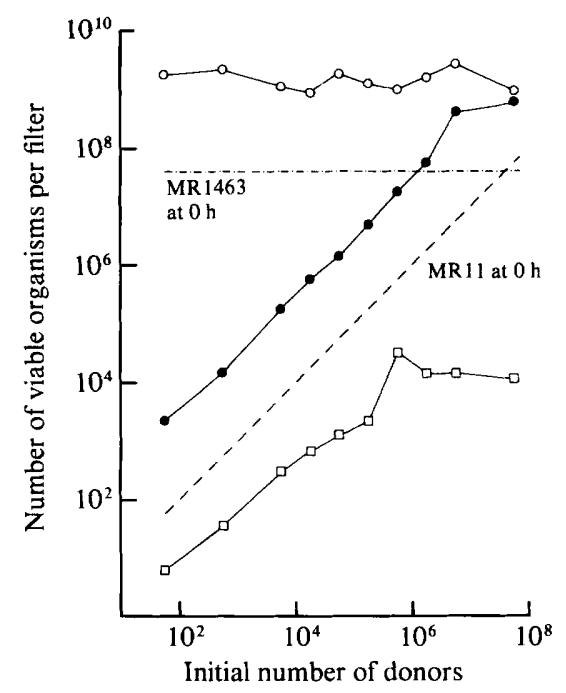

Fig. 2. Dependence of $a u t^{+}$transfer on the number of mating partners per filter. For each assay a constant number of cells of MR 1463 (recipient) was mixed with a varied number of cells of MR 11 (donor) on membrane filters. After $48 \mathrm{~h}$ the bacterial lawns were rinsed from the filters, and the cells were evenly resuspended, diluted, and plated for incubation under selective conditions. The initial numbers of recipient and donor cells are indicated by the dashed lines; $O$, cells of MR 1463 after $48 \mathrm{~h}$; - cells of MR11 after $48 \mathrm{~h} ; \square$, autotrophic transconjugants after $48 \mathrm{~h}$.

Table 4. Influence of medium on the yield of transconjugants formed in the cross MR11 $\left(\right.$ aut $\left.^{+}\right) \times M R 1463$ (aut ben lac rif str)

\section{Additions to MM agar}

Fructose $(2 \%)+$ tryptose $(0 \cdot 1 \%)+$ yeast extract $(0 \cdot 1 \%)$

Fructose $(0.5 \%)+$ tryptose $(0.1 \%)+$ yeast extract $(0.1 \%)$

Fructose $(0.1 \%)+$ tryptose $(0.1 \%)+$ yeast extract $(0.1 \%)$

Fructose $(0.5 \%)$

Nutrient broth $(0.8 \%)$

Pyruvate $(0.5 \%)$

Hexadecane (in gas phase)

Tryptose $(0 \cdot 1 \%)+$ yeast extract $(0.1 \%)$

Sodium citrate $(0.5 \%)$

$\mathrm{H}_{2} / \mathrm{O}_{2} / \mathrm{CO}_{2}$ gas phase

$\begin{array}{cc}\text { Growth } & \begin{array}{c}\text { Number of } \\ \text { transconjugants }\end{array} \\ \left(A_{436}\right)^{*} & \text { (c.f.u. per filter) } \dagger\end{array}$

$43.9 \quad 9.4 \times 10^{2}$

$24.1 \quad 4.6 \times 10^{5}$

$13.7 \quad 2.4 \times 10^{4}$

$27.4 \quad 2.0 \times 10^{4}$

$11.6 \quad 4.1 \times 10^{3}$

$11.9 \quad 1.6 \times 10^{3}$

$7.3 \quad 2.6 \times 10^{5}$

$5.7 \quad 5.0 \times 10^{3}$

$5.1 \quad 1.1 \times 10^{3}$

$2.5 \quad 9.6 \times 10^{3}$

* Turbidity of the bacterial suspension after collecting cells from the membrane filter.

$\uparrow$ The number of colony-forming units (c.f.u.) was determined on $\mathrm{MM} /$ streptomycin plates incubated under $\mathrm{H}_{2} / \mathrm{O}_{2} / \mathrm{CO}_{2}$.

The yield of transconjugants was remarkably influenced by the medium on which conjugation occurred (Table 4). FTY agar resulted in the highest yield of transconjugants. As the table indicates, there was a slight correlation between the cell density reached within $48 \mathrm{~h}$ growth and the number of transconjugants; substrates that allowed only low cell yields also resulted in low yields of transconjugants. There were two exceptions to this. (i) Hexadecane, which is an excellent substrate for growth of $N$. opaca in liquid media, made a high yield of transconjugants possible, but supported only a low cell yield. The limited cell yield was probably due to the fact that hexadecane was supplied to the bacterial lawn on the membrane filters via the gas phase, and thus limited growth. (ii) An increased fructose concentration ( $2 \%)$ resulted in a high cell density, but in a low yield of transconjugants. Under these 
Genetic transfer of hydrogen autotrophy

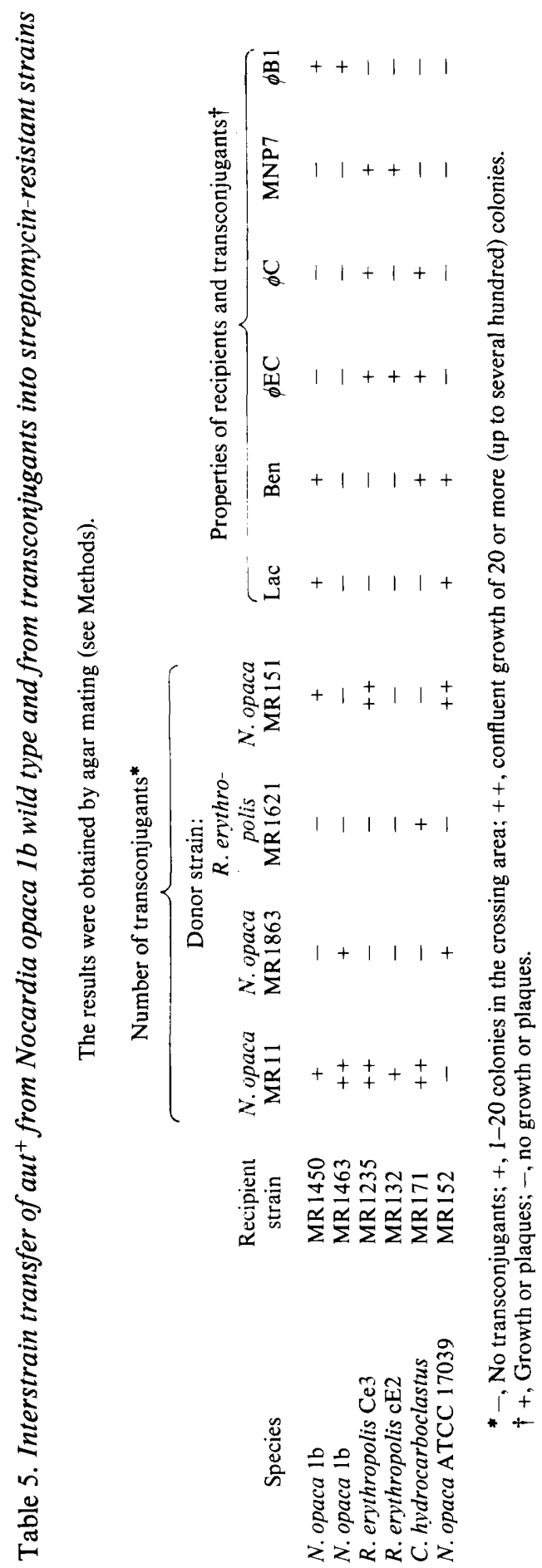


Table 6. Curing frequencies of transconjugants

FTY liquid media with and without mitomycin C were inoculated with bacteria from single autotrophically grown colonies as described in Methods. Samples of these cultures were diluted after $6 \mathrm{~d}$ (after $3 \mathrm{~d}$ for controls) and spread on FTY agar. After incubation, 2000-4000 colonies from each strain were transferred by replica plating on to mineral agar plates and scored for autotrophic growth. The frequency of $\mathrm{Aut}^{-}$colonies is expressed as a percentage of the total colonies.

\begin{tabular}{|c|c|c|c|c|}
\hline Species & Strain & Origin & $\begin{array}{l}\text { Spontaneous } \\
\text { frequency } \\
(\%)\end{array}$ & $\begin{array}{c}\text { Curing by } \\
\text { mitomycin C } \\
(\%)\end{array}$ \\
\hline N. opaca $1 \mathrm{~b}$ & $\begin{array}{l}\text { MR 11 } \\
\text { MR1857 } \\
\text { MR1859 } \\
\text { MR1861 } \\
\text { MR1864 }\end{array}$ & $\begin{array}{c}\text { Wild type } \\
\text { MR11 } 11 \text { MR } 1463 \\
\text { MR11 } 11 \text { MR } 1463 \\
\text { MR 11 } \times \text { MR } 1450 \\
\text { MR151 } 15 \text { MR } 1450\end{array}$ & $\begin{array}{l}0 \cdot 3 \\
2 \cdot 6 \\
6 \cdot 0 \\
2 \cdot 4 \\
8 \cdot 4\end{array}$ & $\begin{array}{r}3 \cdot 7 \\
16 \cdot 5 \\
12 \cdot 3 \\
15 \cdot 9 \\
52 \cdot 6\end{array}$ \\
\hline R. erythropolis $\mathrm{Ce} 3$ & $\begin{array}{l}\text { MR1621 } \\
\text { MR1625 }\end{array}$ & $\begin{array}{l}\text { MR } 113 \times \text { MR } 12 \\
\text { MR } 151 \times \text { MR1235 }\end{array}$ & $\begin{array}{l}19 \cdot 8 \\
100\end{array}$ & $\begin{array}{l}73 \cdot 1 \\
100\end{array}$ \\
\hline R. erythropolis $\mathrm{cE} 2$ & MR 1623 & MR $11 \times$ MR 132 & $73 \cdot 1$ & 100 \\
\hline N. opaca АТCC 17039 & MR151 & MR $1863 \times$ MR 15 & $29 \cdot 4$ & $97 \cdot 0$ \\
\hline C. hydrocarboclastus & MR206 & MR $11 \times$ MR171 & 100 & 100 \\
\hline
\end{tabular}

conditions fragmentation of the cell hyphae and long rods did not occur; this again indicates a correlation between morphogenesis and genetic transfer.

\section{The transfer of autotrophy to other species}

Nocardia opaca belongs to the Rhodococcus taxon (Goodfellow \& Alderson, 1977). Among the strains and species of this genus genetic transfer and recombination are well known. Several species of this taxon were therefore included as potential recipients of the autotrophic marker (Table 5). Autotrophic transconjugants were obtained in most cases, provided the wild-type of $N$. opaca $1 \mathrm{~b}$ (MR11) was used as the donor strain.

Transconjugants isolated from the membrane filters were examined for the non-selective markers and proved to have the markers of the heterotrophic partners. Some transconjugants were examined for their ability to function as donors of the $a u t^{+}$marker. All of them had this ability; however, the infertility of certain matings indicated that apparently each donor has a different spectrum of recipients with which it can mate successfully.

\section{Instability of transconjugants}

Autotrophically grown colonies of various transconjugants showed sectored colony growth; the sectors were areas of diminished growth. Sectored growth was especially pronounced in colonies of transconjugants of heterologous matings. The loss of autotrophy occurred at a high rate even among transconjugants resulting from crosses between $N$. opaca $1 \mathrm{~b}$ partners derived from colonies which did not show obvious sectored growth (Table 6). The frequency of loss was at least one order of magnitude higher than in the wild type.

Aiming at the selection of a more stable strain, the transconjugant MR1621, characterized by an especially low stability, was cultivated under autotrophic conditions for four transfers. Neither this procedure nor the growth of this strain under autotrophic conditions for several years for maintenance in the culture collection resulted in an increase of stability. Recombination of the autotrophic genes into the bacterial chromosome therefore appears rather improbable.

\section{DISCUSSION}

The genetic exchange between Nocardia opaca $1 \mathrm{~b}$ and Rhodococcus erythropolis described in this paper is evidently different from the mating system in $R$. erythropolis as described by Brownell (1978). (i) The genetic exchange concerns only a single marker, namely autotrophic 
growth. Evidence for the transfer of further markers has been found neither by selection for other markers nor by analysis of the autotrophic transconjugants. On the basis of these results the involvement of two complete genomes seems improbable. (ii) The instability of the transconjugants is consistent with the extrachromosomal location of the $a u t^{+}$marker. Even the transconjugants formed in homologous matings of Nocardia opaca $1 \mathrm{~b}$ lost the autotrophic character at a frequency ten times higher than did the wild type. In the transconjugants resulting from heterologous matings the loss frequency was a further order of magnitude higher.

There is a faint similarity of our mating system to the mating types of Nocardia opaca (Brownell, 1978) and of Mycobacterium smegmatis (Mizuguchi et al., 1976) with respect to the spectra of recipients giving fertile mating with the wild type and the transconjugants as donors (Table 5). These phenomena can not yet be explained.

There are two convincing criteria for the location of the genetic information for autotrophic growth on a plasmid: (i) the transfer of the autotrophic character occurs independently of chromosomal markers, and (ii) the autotrophic character maintains its autonomy in the recipient cell and can be irreversibly lost. These were the original criteria for the resistance factors of the Enterobacteriaceae (Watanabe, 1963). Specific arguments opposing the plasmid hypothesis of the autotrophic character in $N$. opaca 1 b concern the failure to 'cure' the bacterium by means of intercalating dyes or rifampicin.

The location on a plasmid of the $a u t^{+}$marker, comprising the determinants at least for hydrogenase and the component enzymes of the Calvin cycle, is an especially attractive hypothesis; it could explain the vast distribution of the ability to grow autotrophically among diverse taxonomic groups of soil and water bacteria, including nitrogen-fixing bacteria such as Rhizobium japonicum, Derxia gummosa and Azospirillum lipoferum. In this respect hydrogen autotrophy may be envisaged as only one of the various peripheral catabolic pathways present in soil bacteria in which plasmid-coded enzymes are involved (Wheelis, 1975).

During the isolation of mutants of Alcaligenes eutrophus H16, no observations indicative of plasmids coding for the whole set of autotrophic enzymes were made (Schink \& Schlegel, 1978). Mutants derived at high frequencies from A. eutrophus type strain, from $A$. eutrophus strain $\mathrm{H} 1$ and from Pseudomonas facilis, by mitomycin $\mathrm{C}$ treatment (K. Andersen, W. R. King \& R. C. Tait, personal communication; Pootjes, 1977), lacked hydrogenase activities, but contained the information for ribulosebisphosphate carboxylase and phosphoribulokinase. Physical evidence was provided for the existence in the wild-type strains of a large plasmid (mol. wt approximately $200 \times 10^{6}$ ) which is absent from the hydrogenase-negative mutants. In contrast, treatment of $A$. eutrophus type strain by classical mutagenic agents resulted in various classes of mutants having only low specific activities of ribulosebisphosphate carboxylase (Andersen, 1979). Agar mating of $A$. eutrophus $\mathrm{H} 16$ with hydrogenase-negative mutants of various strains of this species resulted in transconjugants which had recovered the ability to grow autotrophically and to form hydrogenase. When using spontaneous hydrogenase-negative mutants of $A$. eutrophus type strain as recipients, the transfer frequency was particularly high. These strains were plasmid-free, while donors, transconjugants and mutagen-treated hydrogenase-negative strains contained a large plasmid (mol. wt $260 \times 10^{6}$ ) designated pHG1. It is concluded that a determinant for hydrogenase activity is carried by this self-transmissible plasmid (Friedrich et al., 1981).

A plasmid with a molecular weight of about $190 \times 10^{6}$ carrying a determinant for hydrogenase activity beside a determinant for nodulation activity has been found in Rhizobium leguminosarum strain $128 \mathrm{C} 53$. Although it is not self-transmissible it could be transferred to other strains of $R$. leguminosarum after recombination with a transmissible $R$. leguminosarum plasmid (Brewin et al., 1980). Whether the structural genes or other determinants for hydrogenase expression are carried by the plasmids has so far not been revealed. 
The technical assistance of Monika Dürre is gratefully acknowledged. We appreciate advice given by Professor D. A. Hopwood. The work was supported by Förderungsmittel des Landes Niedersachsen.

\section{REFERENCES}

Abdelal, A. T. \& Schlegel, H. G. (1974). Purification and regulatory properties of fructose 1,6-diphosphatase from Hydrogenomonas eutropha. Journal of Bacteriology 120, 304-310.

Adams, J. N. \& Bradley, S. G. (1963). Recombination events in the bacterial genus Nocardia. Science 140, 1392-1394.

AgGaG, M. \& Schlegel, H. G. (1973). Studies on a Gram-positive hydrogen bacterium, Nocardia opaca strain lb. I. Description and physiological characterization. Archiv für Mikrobiologie 88, 299318.

AgGaG, M. \& Schlegel, H. G. (1974). Studies on a Gram-positive hydrogen bacterium, Nocardia opaca 1b. III. Purification, stability and some properties of the soluble hydrogen dehydrogenase. Archives of Microbiology 100, 25-39.

AMACHI, T. \& BOWIEN, B. (1979). Characterization of two fructose bisphosphatase isoenzymes from the hydrogen bacterium Nocardia opaca 1b. Journal of General Microbiology 113, 347-356.

ANDERSEN, K. (1979). Mutations altering the catalytic activity of a plant-type ribulosebisphosphate carboxylase/oxygenase in Alcaligenes eutrophus. Biochimica et biophysica acta 585, 1-11.

Bowien, B. \& SCHLEGEl, H. G. (1981). Physiology and biochemistry of aerobic hydrogen-oxidizing bacteria. Annual Review of Microbiology 35, (in the Press).

Brewin, N. J., De Jong, T. M., Phillips, D. A. \& Johnston, A. W. B. (1980). Co-transfer of determinants for hydrogenase activity and nodulation ability in Rhizobium leguminosarum. Nature, London 288. 77-79.

Brownell, G. H. (1978). Genetic interactions in the genus Nocardia. In Genetics of the Actinomycetales, pp. 137-148. Edited by E. Freerksen, I. Tarnok \& J. H. Thumin. Stuttgart \& New York: Gustav Fischer Verlag.

Brownell, G. H., Adams, J. N. \& Bradley, S. G. (1967). Growth and characterization of nocardiophages for Nocardia canicruria and Nocardia erythropolis mating types. Journal of General Microbiology 47, 247-256.
Friedrich, B., Hogrefe, C. \& Schlegel, H. G. (1981). Naturally occurring genetic transfer of hydrogen-oxidizing ability between strains of Alcaligenes eutrophus. Journal of Bacteriology 147, 198-205.

Goodfellow, M. G. \& Alderson, G. (1977). The actinomycete genus Rhodococcus: a home for the 'rhodochrous' complex. Journal of General Microbiology 100, 99-122.

Matney, T. S. \& Achenbach, N. E. (1962). A comment on the fertility of $F_{2}$ donor types of Escherichia coli K-12. Biochemical and Biophysical Research Communications 9, 285-287.

Mizuguchi, Y., Suga, K. \& Tokunaga, T. (1976). Multiple mating types of Mycobacterium smegmatis. Japanese Journal of Microbiology 20, 435-443.

Pootjes, C. F. (1977). Evidence for plasmid coding of the ability to utilize hydrogen gas by Pseudomonas facilis. Biochemical and Biophysical Research Communications 76, 1002-1006.

ReH, M. \& Schlegel, H. G. (1975). Chemolithoautotrophie als eine übertragbare, autonome Eigenschaft von Nocardia opaca 1b. Nachrichten der Akademie der Wissenschaften Göttingen 12 , $1-10$.

Schink, B. \& Schlegel, H. G. (1978). Mutants of Alcaligenes eutrophus defective in autotrophic metabolism. Archives of Microbiology 117, 123129.

Schlegel, H. G., Kaltwasser, H. \& Gottschalk, G. (1961). Ein Submersverfahren zur Kultur wasserstoffoxidierender Bakterien: wachstumsphysiologische Untersuchungen. Archiv für Mikrobiologie 38, 209-222.

Schneider, K. \& Schlegel, H. G. (1977). Localization and stability of hydrogenases from aerobic hydrogen bacteria. Archives of Microbiology 112 , 229-238.

Watanabe, T. (1963). Infective heredity of multiple drug resistance in bacteria. Bacteriological Reviews 27, 87-115.

WheELIS, M. L. (1975). The genetics of dissimilatory pathways in Pseudomonas. Annual Review of Microbiology 29, 505-524. 